\title{
Analisis redesain Sistem Mixer Cement sebagai Pengolahan Limbah Batubara di PT. X
}

\author{
Analysis of redesain system of Cement Mixer as \\ Coal waste processing in PT. $X$ \\ Firman Yasa Utama ${ }^{1}$, Huda Mei Setio ${ }^{2}$, Soeryanto ${ }^{3}$ \\ firmanutama@unesa.ac.id
}

\begin{abstract}
Suplai utama kelistrikan di Indonesia di dapatkan dari 7 PLTU yang tersebar di berbagai wilayah. PLTU menggunakan bahan bakar batubara untuk memanaskan steam, setiap harinya satu PLTU membuang limbah batubara sebanyak 300 ton. Jika ada 7 rumah berarti setiap harinya industri kelistrikan membuang limbah batubara sebanyak 2100 ton. Hakko Industri Ltd. bekerja sama dengan PT. X melakukan pengolahan limbah batubara untuk dijadikan produk bangunan seperti paving blok. Dilanjutkan kerjasama PT. $X$ dengan JICA dan LIPI yang telah mendesain dan menciptakan mesin mixer cement. Namun masih banyak kekurangan dari mesin yang sudah diciptakan ini, sehingga PT. X membutuhkan desain baru guna memperoleh hasil yang lebih baik dari sebelumnya dengan analisis desain dan konsep. Metode yang digunakan dengan redesain mesin mixer cement dan analisis pada sistem elektrik maupun bentuk blade atau pengaduk. Dari empat desain baru $(A, B, C, D)$ yang sudah dibuat, tipe $D$ adalah yang terbaik. Adapun indikatornya, dapat melakukan mixer dan pengeluaran hasil mixer cement secara otomatis, gerakan motor dan proses adukan lebih ringan dan rata.
\end{abstract}

Kata Kunci : limbah batubara, mixer cement, redesain, blade, otomatis

The main electricity supply in Indonesia in the get from 7 PLTU scattered in different areas. PLTU use the coal fuel to heat the steam, each day a coal waste many as $\mathbf{3 0 0}$ tons. If there are 7 plant mean daily electrical waste coal industry as much as 2100 tonnes. Hakko Industri Ltd. cooperated with PT $X$ do coal waste processing for building products such as paving blocks. Continued cooperation PT. X with JICA and the LIPI has been designing and creating machine mixer cement. But there are still many shortcomings of machines that are already created, so $P T X$ requires a new design in order to obtain better results than ever before with the analysis of design and concept. The method is used with the redesain machine mixer cement and analysis on electrical system as well as the shape of the blade or mixer. From the four new design ( $A, B, C, D)$ that's been created, type $D$ is the best. As for the charge indicators will, can do a mixer and cement mixer results spending automatically, motor movement and the process of slurry lighter and flat.

Key Words : coal waste, mixer cement, redesgin, blade, automatic

\section{Pendahuluan}

Suplai utama kelistrikan di Indonesia di dapatkan dari 7 PLTU yang tersebar di berbagai wilayah. PLTU menggunakan bahan bakar batubara untuk memanaskan steam. Setiap harinya satu PLTU menghasilkan limbah batubara sebanyak 300 ton. Jika ada 7 PLTU berarti setiap harinya industri listrikan membuang limbah batubara sebanyak 2100 ton. Hakko Industri Ltd. bekerja sama dengan PT. X melakukan pengolahan limbah batubara untuk dijadikan produk bangunan seperti paving blok. Dilanjutkan kerjasama PT. X dengan JICA dan LIPI yang telah mendesain dan menciptakan mesin mixer cement. Namun masih banyak kekurangan dari mesin yang sudah diciptakan ini, sehingga PT. X membutuhkan desain baru guna memperoleh hasil yang lebih baik dari sebelumnya dengan analisis desain dan konsep. Pada divisi R\&D berinisiatif ingin mengembangkan mesin mixer cement yang lebih efektif dan lebih efisien sebagai rekomendasi untuk PT. X agar dapat diproduksi secara massal.

\section{TINJAUAN PUSTAKA}

Guna memunjang masalah yang terjadi diatas, maka dilakukan redesain sistem mixer cement sebagai upaya perbaikan fungsi khususnya pada sistem elektrikal. Proses redesain menggunakan berbagai tools untuk membantu memudahkan. Adapun tools yang dimaksud antara lain perangkat lunak Autodesk Inventor Profesional 2013 dan komponen-komponen elektrikal.

A. Autodesk Inventor Profesional 2013

Adalah program pemodelan solid berbasis fitur parametrik, artinya semua objek dan hubungan antargeometri dapat dimodifikasi kembali meski geometrinya sudah jadi tanpa perlu mengulang lagi dari awal. Tidak hanya sampai pada menampilkan gambar kerja, Autodesk Inventor Profesional 2013 juga mampu memberikan simulasi pergerakan dari produk yang kita desain serta mempunyai alat untuk menganalisis kekuatan. Tool ini cukup mudah digunakan dan dapat membantu kita untuk mengurangi kesalahan dalam membuat desain. Dengan demikian, selain biaya yang harus kita keluarkan akan berkurang, time to market dari benda yang kita desain pun dapat dipercepat karena kita sudah mensimulasikan terlebih dahulu benda yang kita desain di komputer sebelum masuk ke proses produksi.

Menu dan Toolbar Autodesk Inventor Profesional 2013

Seperti halnya program lain, Autodesk Inventor Profesional 2013 memiliki pula bidang kerja, yaitu Menu Bar, Standard Toolbar, Panel Bar, dan Browser Bar. 


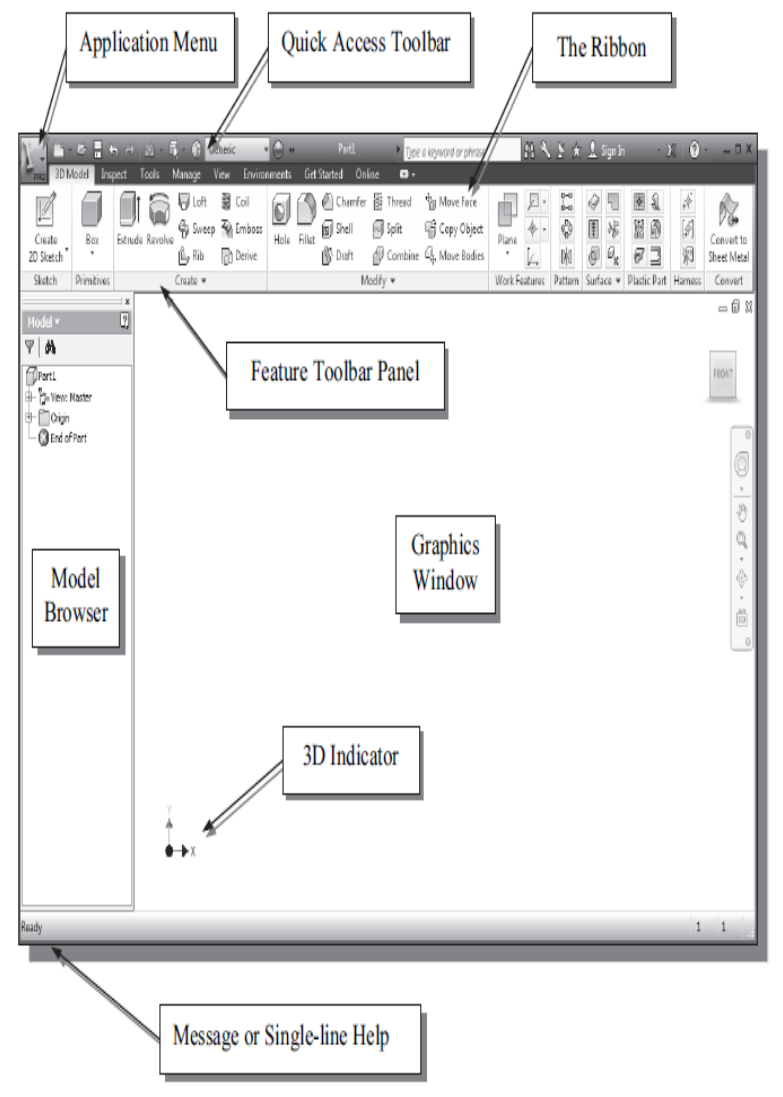

\section{Gambar 2.1 Menu dan Toolbar Autodesk Inventor Profesional 2013}

Menu Bar berisi semua perintah yang terdapat di Autodesk Inventor Profesional 2013. Standard Toolbar berisi perintah yang digunakan selama proses menggambar. Panel Bar berisi perintah khusus untuk menunjang proses yang sedang berangsung. Misalnya, kita membuat gambar dengan template "Sheet Metal.ipt" maka pada Panel Bar secara otomatis akan muncul perintah khusus untuk Sheet Metal. Browser Bar berisi langkah-langkah kerja. Misalnya, kita membuat objek dengan Extrude dan Revolve, semua akan tercatat di Browser Bar untuk memudahkan kita melakukan edit ulang.

a. Sistem Navigasi

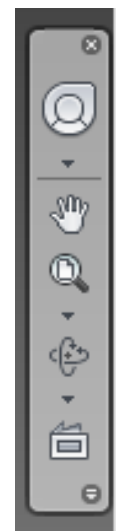

Gambar 2.2 Sistem Navigasi
Pada Autodesk Inventor Profesional 2013 terdapat tool-tool navigasi yang membantu mobilitas saat menggambar di dalam bidang kerja. Kita dapat menemui tools tersebut seperti zoom, rotate, pan, dan lainnya pada Inventor Standard Toolbar.

- Zoom Fungsinya untuk memperbesar gambar pada tampilan bidang kerja. Klik zoom lalu klik pada bidang kerja dan geser kursor ke atas atas ke bawah. Kemudian, kliklah untuk mendapatkan tampilan yang diinginkan. Kita dapat menggunakan zoom ketika tools lain sedang aktif.

- Pan Fungsinya untuk menggeser tampilan bidang kerja. Kliklah pan lalu klik pada bidang kerja. Selanjutnya, geserlah kursor pada tempat yang dinginkan.

- Free Orbit Fungsinya untuk memutar objek pada bidang kerja. Kliklah free orbit, lalu klik pada bidang kerja. Selanjutnya, putar objek sampai memperoleh tampilan yang diinginkan.

Full Navigation Wheel Fungsinya untuk melakukan kombinasi perintah navigasi seperti zoom, orbit, pan, dan lain-lain. Kliklah full navigation wheel sehingga akan keluar menu dan pilihlan salah satu perintah yang akan dipakai.

\section{b. Sketch}

Sketch memiliki peranan penting karena merupakan cikal bakal dalam membuat gambar 3D Model atau Part. Sketch hanya terdiri dari gambar geometri. Sketch dibuat sesederhana mungkin karena akan mempermudah proses desain. Untuk finishing detail, gunakan seperti Fillet, Chamfers, \& Face Draft pada 3D model atau part. Untuk membuat gambar solid, pastikan sketch dalam keadaan tertutup atau tersambung dengan menggunakan Coincident Constraint atau Trim, Extend Curve. Setelah Sketch selesai, terlebih dahulu lakukan Constraint sebelum dimension. Apabila langkah membuka Autodesk Inventor Profesional 2013 telah selesai dilakukan maka kita bisa langsung melakukan Sketch yang kita inginkan sesuai tampilan berikut ini.

Selanjutnya pada bidang kerja kita bisa langsung membuat Sketch seperti Line, Circle, Arc, dan lainlain. Untuk Sketch Default, sketch terdapat pada bidang XY Plane. Kita dapat membuat sketch di Work Plane dan Planar Face (permukaan datar). Setelah selesai Sketch kiklah tombol Finish Sketch. Sketch di Autodesk Inventor Profesional 2013 dibagi 2 jenis, yaitu 2D sketch dan 3D sketch.

1. 2D Sketch 


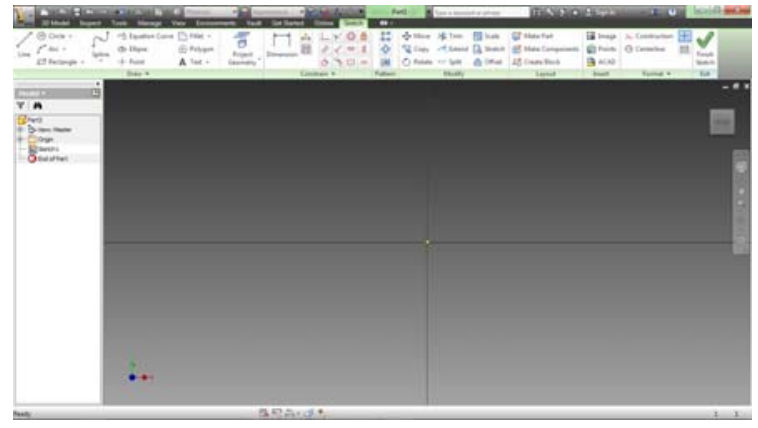

Gambar 2.3 Tampilan Sketch 2D

2D Sketch pada Autodesk Inventor Profesional 2013 hampir mirip saat kita menggambar 2D pada Autodesk Autocad. Oleh karena itu, seseorang yang telah menguasai Autodesk Autocad tidak akan kesulitan dalam mempelajarinya.

Berikut alat-alat Draw pada Sketch 2D.

* Line dan Spline

Line berfungsi membuat garis lurus, sedangkan Spline untuk membuat garis kurva dengan titik Point tertentu. Selain Spline terdapat pula Bridge Curve.

Circle Fungsinya untuk membuat lingkaran. Di sini terdapat 3 cara dalam membuat lingkaran, yaitu Center Point Circle, Tangent Circle, dan Ellipse.

Arc Fungsinya untuk membuat garis busur. Di sini terdapat tiga cara dalam membuat Arc, yaitu: Three Point Arc, Tangent Arc, dan Center Point Arc.

Rectangle Fungsinya untuk membuat kotak persegi panjang atau bujur sangkar Di sini terdapat 2 cara dalam membuat Rectangle, yaitu : Two Point Rectangle dan Three Point rectangle.

2. 3D Sketch

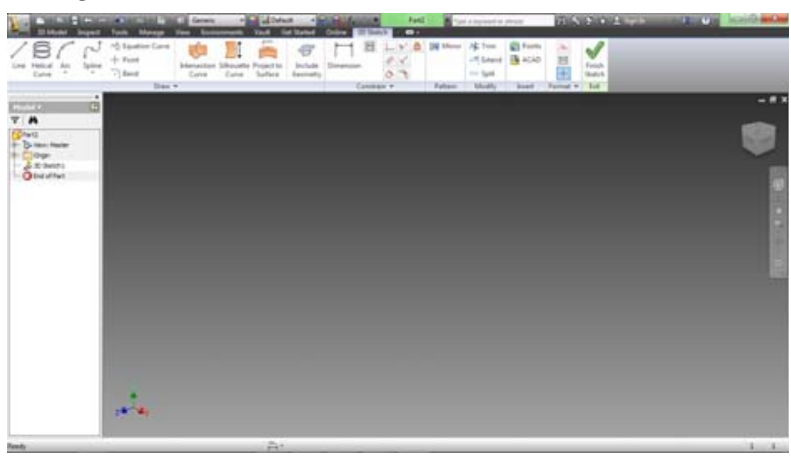

Gambar 2.4 Tampilan Sketch 3D

Fungsinya untuk membat sketch pada 3 sumbu $(\mathrm{X}, \mathrm{Y}, \mathrm{Z})$, sedangkan 2D sketch hanya pada 2 sumbu $(\mathrm{X}, \mathrm{Y})$. Dengan 3D sketch kita dapat membat sketch yang tidak hanya 2 sumbu, misalnya jalur pipa yang berkelok-kelok, membuat desain sudu turbin, dll. Pada Autodesk Inventor Professional 2013, 2D sketch merupakan Default Sketch. Untuk mengaktifkan 3D sketch kita harus Finish Sketch pada 2D sketch lalu kliklah 3D Sketch.

Beberapa alat pada 3D sketch yaitu:

* Line dan Spline : Line digunakan untuk membuat garis lurus. Spline digunakan untuk membuat garis kurva dengn titik Point tertentu.

* Bend Fungsinya untuk membuat pertemuan antara 2 garis (line) menjadi cembung atau cekung.

* 3D Intersection Curve Fungsinya untuk membuat kurva 3D dengan hasil perpotongan 2 Face, Surface, dan 2D Sketch.

* Project Curve to Surface Fungsinya untuk membuat kurva 3D dengan perpaduan 2D Curve Sketch dan Surface.

* Helical Curve Fungsinya untuk membuat kurva spiral.

c. Part

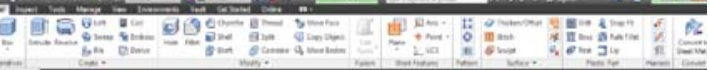

Gambar 2.5 Tampilan Part

Setelah memahami Sketch yang merupakan dasar pembuatan Part, kita akan mengulas Part. Pada Autodesk Inventor Profesional 2013 gambar Part dibedakan menjadi 2 macam, yaitu:

a. Solid, yaitu objek yang padat

b. Surface, yaitu objek yang tidak padat, hanya berupa kulit.

d. Assembly

$\nabla$ Assembly - Assemble $2 \mathrm{D}$ and $3 \mathrm{D}$ components

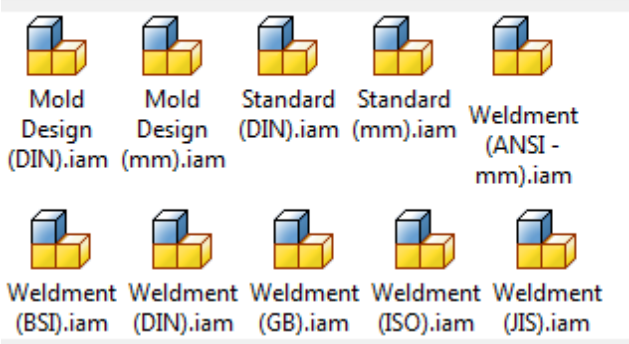

\section{Gambar 2.6 Opsi Assembly}

Dalam mendesain sebuah mesin atau produk yang terdiri atas berbagai macam Part kita akan membutuhkan Assembly sebagai tema untuk merakit. Di dalam Assembly, kita dapat melakukan berbagai macam pekerjaan, seperti melakukan modifikasi Part, simulasi fungsi alat, sampai berbagai macam analisis lainnya. Dengan demikian, pekerjaan kita dalam mendesain akan lebih mudah. Assembly sendiri terdiri atas Single Part dan Sub Assembly yang semuanya ada di dalam File Assembly. Di dalam Assembly yang besar dan memiliki banyak Part buatlah beberapa Assembly kecil atau Sub Assembly. Adanya Sub 
Assembly akan mempercepat proses modifikasi Part dan memudahkan pensarian karena akan membentuk kelompok-kelompok kecil.

Di bawah ini terdapat daftar list tipe file yang dapat anda gunakan dalam Autodesk Inventor:

- Autodesk Inventor parts and assemblies (*.ipt, *.iam)

- $\quad$ Autedesk Mechanical Desktop (*.dwg)

- $\quad$ Autodesk Autocad (*.dwg)

- $\quad$ file SAT(ACIS/ShapeManager) (*.sat)

- $\quad$ file IGES (*.igs, *ige, *.iges)

- $\quad$ file STEP (*.stp, *.ste, *.step)

- Pro Enginer (*.prt, *.afm) Assembly Constraint

Kita menggunakan assembly constraints untuk menciptakan hubungan parametris antara tiap komponen dalam tiap assembly. Sebagaimana anda menggunakan 2D konstrain untuk mengontrol geometri 2D, menggunakan $3 \mathrm{D}$ assembly constrain dalam sebuah assembly untuk mengatur posisi sebuah komponen dalam hubungannya dengan komponen yang lain.

Basic assembly constrain terdiri dari empat macam yang akan dijelaskan sebagai berikut:

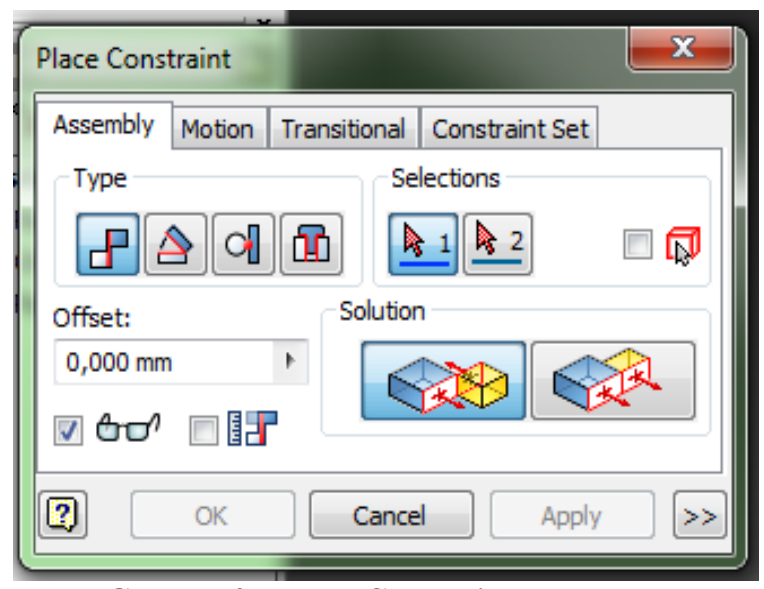

Gambar 2.7 Place Constraint

- $\quad$ Mate/Flush Constraint

Digunakan untuk meluruskan part feature seperti permukaan rusuk atau sumbu suatu part ke part yang lain.

- Angle Constraint

Digunakan untuk memberikan sudut antara dua buah part bisa diaplikasikan ke permukaan datar, garis rusuk yang datar atau sumbu-sumbu.

- $\quad$ Tangent Constraint

Digunakan untuk membuat sebuah hubungan tangensial antara permukaan dari dua buah part. Salah satu part tersebut harus merupakan permukaan lengkung.
- Insert Constraint

Digunakan untuk memasukkan sebuah komponen ke komponen lain seperti baut poros dan lain-lain kedalam lubang pasangannya pada komponen lain. Konstrain ini mengkombinasikan sebuah mate constraint antara dua sumbu dan sebuah mate constraint antara dua permukaan datar. Konstrain ini diterapkan dengan memilih edge circular pada tiap part.

A. Sistem Electrical Mixer Cement Kapasitas 208 Liter

1. Magnetic Contactor (MC) tipe S-K10

Magnetic Contactor (MC) adalah sebuah komponen yang berfungsi sebagai penghubung / kontak dengan kapasitas yang besar dengan menggunakan daya minimal. Kontaktor magnet yaitu suatu alat penghubung listrik yang bekerja atas dasar magnet yang dapat menghubungkan antara sumber arus dengan muatan. Bila inti koil pada kontaktor diberikan arus, maka koil akan menjadi magnet dan menarik kontak sehingga kontaknya menjadi terhubung dan dapat mengalirkan arus listrik.

Kontaktor magnet atau saklar magnet merupakan saklar yang bekerja berdasarkan prinsip kemagnetan. Artinya sakelar ini bekerja jika ada gaya kemagnetan pada penarik kontaknya. Magnet berfungsi sebagai penarik dan dan sebagai pelepas kontak-kontaknya dengan bantuan pegas pendorong. Sebuah kontaktor harus mampu mengalirkan dan memutuskan arus dalam keadaan kerja normal. Arus kerja normal ialah arus yang mengalir selama pemutusan tidak terjadi. Sebuah kontaktor dapat memiliki koil yang bekerja pada tengangan DC atau AC. Pada tengangan $\mathrm{AC}$, tegangan minimal adalah 85\% tegangan kerja, apabila kurang maka kontaktor akan bergetar.

Kontaktor pada umumnya memiliki kontak utama untuk aliran 3 fasa. Dan juga memiliki beberapa kontak bantu untuk berbagai keperluan. Kontak utama digunakan untuk mengalirkan arus utama, yaitu arus yang diperlukan untuk beban, misalnya motor listrik. Sedangkan kontak bantu digunakan untuk mengalirkan arus bantu yaitu arus yang diperlukan untuk kumparan magnet, alat bantu rangkaian, lampu lampu indikator, dan lain-lain. Untuk menghubungkan kontak utama hanya dengan cara memberikan tegangan pada koil MC sesuai spesifikasinya. Komponen utama sebuah MC adalah koil dan kontak utama. Koil dipergunakan untuk menghasilkan medan magnet yang akan menarik kontak utama sehingga terhubung pada masing masing pole. Magnetic Contactor atau Kontaktor AC sangat cocok untuk digunakan pada sirkuit sampai tegangan 


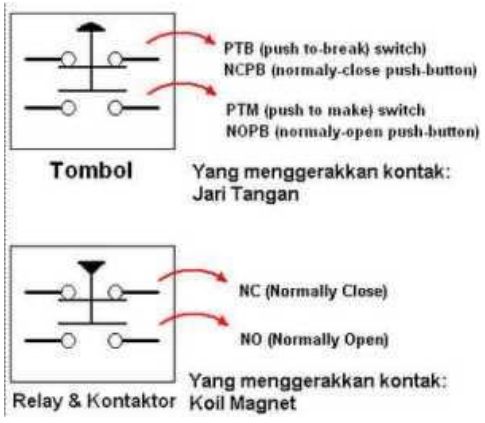

maksimal 690v $50 \mathrm{~Hz}$ atau $60 \mathrm{~Hz}$ dan arus sampai 780A dari 6A.

Prinsip kerja kontaktor magnet dapat dilihat pada gambar berikut :

\section{Gambar 2.8 Prinsip Kerja Kontaktor Magnet}

Kontaktor termasuk jenis saklar motor yang digerakkan oleh magnet. Bila pada jepitan A1 dan A2 kumparan magnet diberi tegangan, maka magnet akan menarik jangkar sehingga kontak-kontak bergerak yang berhubungan dengan jangkar tersebut ikut tertarik. Tegangan yang harus dipasangkan dapat tegangan bolak balik (AC) maupun tegangan searah (DC), tergantung dari bagaimana magnet tersebut dirancangkan. Untuk beberapa keperluan digunakan juga kumparan arus (bukan tegangan), akan tetapi dari segi produksi lebih disukai kumparan tegangan karena besarnya tegangan umumnya sudah dinormalisasi dan tidak tergantung dari keperluan alat pemakai tertentu.

Spesifikasi kontaktor magnet yang harus diperhatikan adalah kemampuan daya kontaktor ditulis dalam ukuran Watt/KW, yang disesuaikan dengan beban yang dipikul, kemampuan menghantarkan arus dari kontak-kontaknya, ditulis dalam satuan ampere, kemampuan tegangan dari kumparan magnet, apakah untuk tegangan 127 Volt atau 220 Volt, begitupun frekuensinya, kemampuan melindungi terhadap tegangan rendah, misalnya ditulis $\pm 20 \%$ dari tegangan kerja. Dengan demikian dari segi keamanan dan kepraktisan, penggunaan kontaktor magnet jauh lebih baik dari pada saklar biasa.

Ukuran dari kontaktor ditentukan oleh batas kemampuan arusnya. Biasanya pada kontaktor terdapat beberapa kontak, yaitu kontak normal membuka (Normally Open $=\mathrm{NO}$ ) dan kontak normal menutup (Normally Close $=\mathrm{NC}$ ). Kontak NO berarti saat kontaktor magnet belum bekerja kedudukannya membuka dan bila kontaktor bekerja kontak itu menutup/menghubung. Sedangkan kontak NC berarti saat kontaktor belum bekerja kedudukan kontaknya menutup dan bila kontaktor bekerja kontak itu membuka. Jadi fungsi kerja kontak NO dan NC berlawanan.

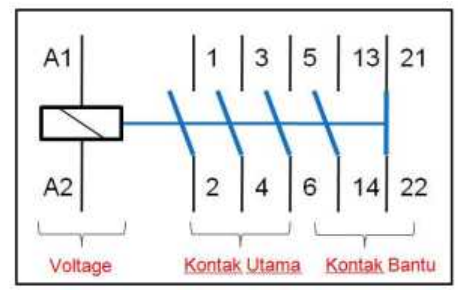

\section{Gambar 2.9 Cara Kerja Kontaktor Magnet}

Kontaktor dapat di analogikan sebagai sebagai Breaker untuk sirkuit pemutus dan penghubung tenaga listrik pada beban. Karena pada Kontaktor selain terdapat kontak NO dan NC juga terdapat 3 buah kontak NO utama yang dapat menghubungkan arus listrik sesuai ukuran yang telah ditetapkan pada kontaktor tersebut. Misalnya 10A, 15A, 20A, 30A, 50A dan seterusnya. Seperti pada gambar dibawah ini.
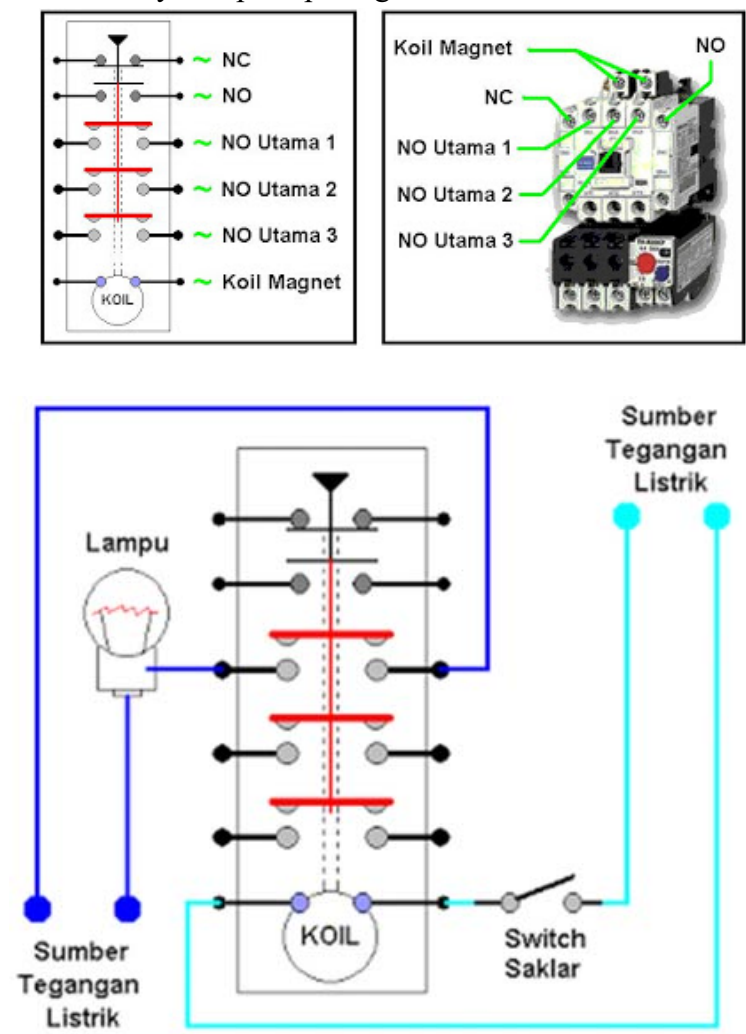

Gambar 2.10 Kontak Internal pada Kontaktor

Fungsi dari kontak-kontak dibuat untuk kontak utama dan kontak bantu. Kontak utama tendiri dari kontak NO dan kontak bantu terdiri dan kontak NO dan NC. Konstruksi dari kontak utama berbeda dengan kontak bantu, yang kontak utamanya mempunyai luas permukaan yang luas 
dan tebal. Kontak bantu luas permukaannya kecil dan tipis.

Notasi dan penomoran kontak-kontak kontaktor sebagai berikut:

Tabel 2.2 Notasi dan Penomoran Kontak-kontak Kontaktor Magnet

\begin{tabular}{|c|c|c|c|c|}
\hline \multirow{2}{*}{ Kontak } & \multicolumn{2}{|l|}{ Notasi } & \multirow{2}{*}{$\begin{array}{l}\text { Jenis } \\
\text { Kontak }\end{array}$} & \multirow[t]{2}{*}{ Penggunaan } \\
\hline & Huruf & Angka & & \\
\hline \multirow[t]{5}{*}{ Utama } & $\begin{array}{l}\text { L1, L2, } \\
\text { L3 }\end{array}$ & 135 & NO & Ke Jala-Jala \\
\hline & R S & & & \\
\hline & $\mathrm{T}$ & 246 & $\mathrm{NC}$ & Ke Motor \\
\hline & U V & & & \\
\hline & W & & & \\
\hline \multirow[t]{5}{*}{ Bantu } & & 1314 & $\mathrm{NO}$ & Pengunci \\
\hline & & 1920 & \multirow{2}{*}{ NO } & \multirow{2}{*}{ Fungsi Lain } \\
\hline & & 3132 & & \\
\hline & & 2122 & & Pengaman \\
\hline & & 4142 & $\mathrm{NC}$ & dan Fungsi \\
\hline \multicolumn{2}{|l|}{ Coil } & $\begin{array}{l}\text { Notasi } \\
\text { Huruf }\end{array}$ & $a-b$ & $\mathrm{~A} 1-\mathrm{A} 2$ \\
\hline
\end{tabular}

\section{Relay tipe OMRON MK2P-I}

Prinsip kerja Relay dan Kontaktor adalah rangkaian pembuat magnet untuk menggerakkan penutup dan pembuka saklar internal didalamnya. Yang membedakan dari kedua peralatan tersebut adalah kekuatan saklar internalnya dalam menghubungkan besaran arus listrik yang melaluinya.

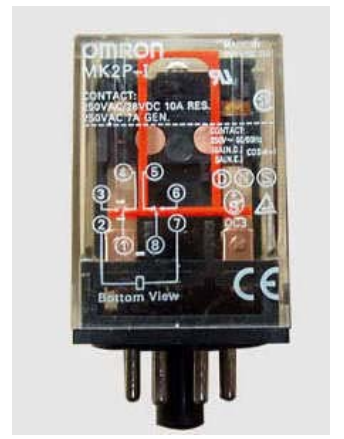

Relay dianalogikan
sebagai pemutus dan penghubung seperti halnya fungsi pada tombol (Push Button) dan saklar (Switch)., yang hanya bekerja pada arus kecil 1A s/d 5A.

\section{Gambar 2.11 Relay tipe OMRON MK2P-I}

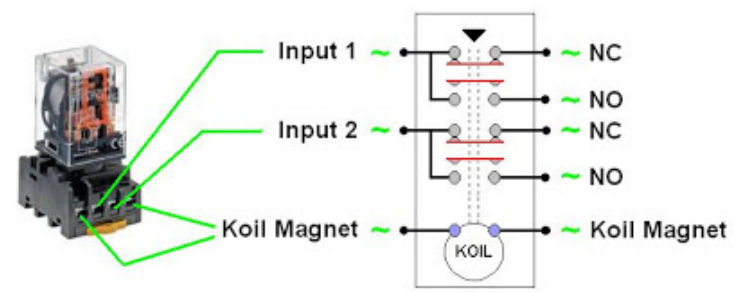

Gambar 2.12 Kontak Internal pada Relay
Pemahaman sederhananya adalah bila kita memberikan arus listrik pada coil relay atau kontaktor, maka saklar internalnya juga akan terhubung. Selain itu juga ada saklar internalnya yang terputus. Hal tersebut sama persis pada kerja tombol push button, hanya berbeda pada kekuatan untuk menekan tombolnya. Saklar internal inilah yang disebut sebagai kontak NO (Normally Open = Bila coil contactor atau relay dalam keadaan tak terhubung arus listrik, kontak internalnya dalam kondisi terbuka atau tak terhubung) dan kontak NC (Normally Close= Sebaliknya dengan Normally Open).

3. Push Button

Push button switch (saklar tombol tekan) adalah perangkat / saklar sederhana yang berfungsi untuk menghubungkan atau memutuskan aliran arus listrik dengan sistem kerja tekan unlock (tidak mengunci). Sistem kerja unlock disini berarti saklar akan bekerja sebagai device penghubung atau pemutus aliran arus listrik saat tombol ditekan, dan saat tombol tidak ditekan (dilepas), maka saklar akan kembali pada kondisi normal.

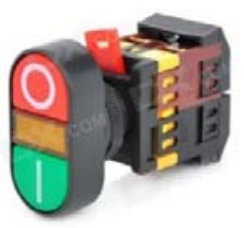

Gambar 2.14 Push Button Switch

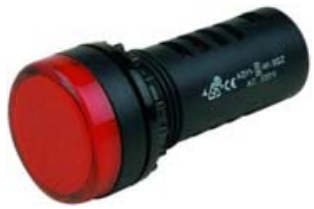

Gambar 2.15 LED

Sebagai device penghubung atau pemutus, push button switch hanya memiliki 2 kondisi, yaitu On dan Off (1 dan 0). Istilah On dan Off ini menjadi sangat penting karena semua perangkat listrik yang memerlukan sumber energi listrik pasti membutuhkan kondisi On dan Off.

Karena sistem kerjanya yang unlock dan langsung berhubungan dengan operator, push button switch menjadi device paling utama yang biasa digunakan untuk memulai dan mengakhiri kerja mesin di industri. Secanggih apapun sebuah mesin bisa dipastikan sistem kerjanya tidak terlepas dari keberadaan sebuah saklar seperti push button switch atau perangkat lain yang sejenis yang bekerja mengatur pengkondisian On dan Off. 


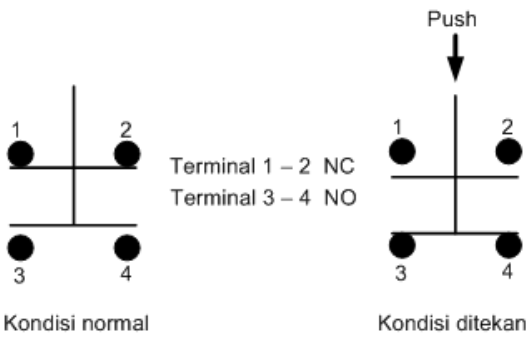

Gambar 2.16 Prinsip Kerja Push Button Switch

Berdasarkan fungsi kerjanya yang menghubungkan dan memutuskan, push button switch mempunyai 2 tipe kontak yaitu NC (Normally Close) dan NO (Normally Open).

- NO (Normally Open), merupakan kontak terminal dimana kondisi normalnya terbuka (aliran arus listrik tidak mengalir). Dan ketika tombol saklar ditekan, kontak yang NO ini akan menjadi menutup (Close) dan mengalirkan atau menghubungkan arus listrik. Kontak NO digunakan sebagai penghubung atau menyalakan sistem circuit (Push Button ON).

- NC (Normally Close), merupakan kontak terminal dimana kondisi normalnya tertutup (mengalirkan arus litrik). Dan ketika tombol saklar push button ditekan, kontak NC ini akan menjadi membuka (Open), sehingga memutus aliran arus listrik. Kontak NC digunakan sebagai pemutus atau mematikan sistem circuit (Push Button Off).

- Motor Induksi 1 Fasa

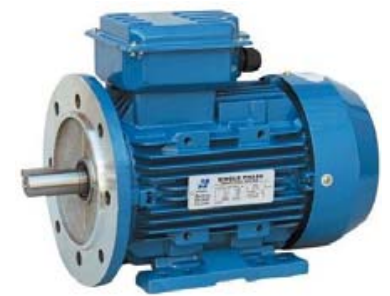

\section{Gambar 2.17 Motor 1 Fasa}

Berdasarkan suplai input yang digunakan, motor induksi dibagi menjadi dua jenis, yaitu motor: induksi 1 fasa dan motor induksi 3 fasa. Dalam artikel ini hanya akan dijelaskan mengenai motor induksi 1 fasa, namun untuk prinsip kerjanya sendiri kedua jenis motor induksi tersebut memiliki prinsip kerja yang sama. Yang membedakan dari kedua motor induksi ini ialah motor induksi 1 fasa tidak dapat berputar tanpa bantuan gaya dari luar sedangkan motor induksi 3 fasa dapat berputar sendiri tanpa bantuan gaya dari luar.

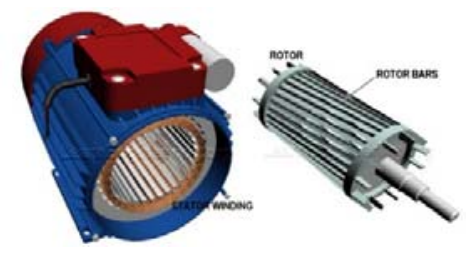

\section{Gambar 2.18 Bagian Utama Motor Induksi 1 Fasa (www.learnengineering.org)}

Terdapat 2 bagian penting pada motor induksi 1 fasa, yaitu: rotor dan stator. Rotor merupakan bagian yang berputar dari motor dan stator merupakan bagian yang diam dari motor. Rotor umumnya berbentuk slinder dan bergerigi sedangkan stator berbentuk silinder yang melingkari seluruh badan rotor. Stator umumnya dilengkapi dengan stator winding yang bertujuan membantu putaran rotor, dimana stator winding dilengkapi dengan konduktor berupa kumparan. Selain itu, stator juga dilapisi dengan lamina berbahan dasar silikon dan besi yang bertujuan untuk mengurangi tegangan yang terinduksi pada sumbu stator dan mengurangi dampak kerugian akibat munculnya arus eddy (eddy current) pada stator. Selain itu, rotor juga dilapisi dengan lamina untuk menambah kinerja dari rotor yang digunakan. Masing-masing komponen dipasang pada besi yang ditunjukkan seperti pada gambar berikut:

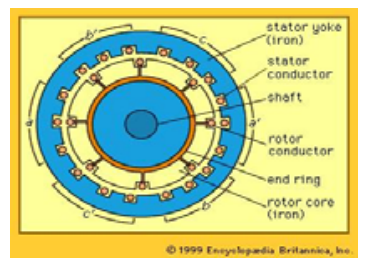

Gambar 2.19 Konstruksi Motor Induksi 1 Fasa

\section{METODE DAN PEMBAHASAN}

Metode redesain mesin mixer cement dengan menyesuaikan sistem elektrik dan mendesain bentuk blade atau pengaduk menggunakan perangkat lunak Autodesk Inventor Profesional 2013. Desain dimaksud meliputi :

1. Desain Mesin Aquades

2. Re-desain dan Modifikasi Sistem Electrical Mixer Cement Kapasitas 208 Liter

3. Penggantian Wind Turbin dengan merek berbeda namun spesifikasi sama

Desain Mesin Aquades maupun Mixer Cement menggunakan aplikasi Autodesk inventor 2013

1. Desain Mesin Aquades

Tabel 3.2 Spesifikasi Mesin Aquades 


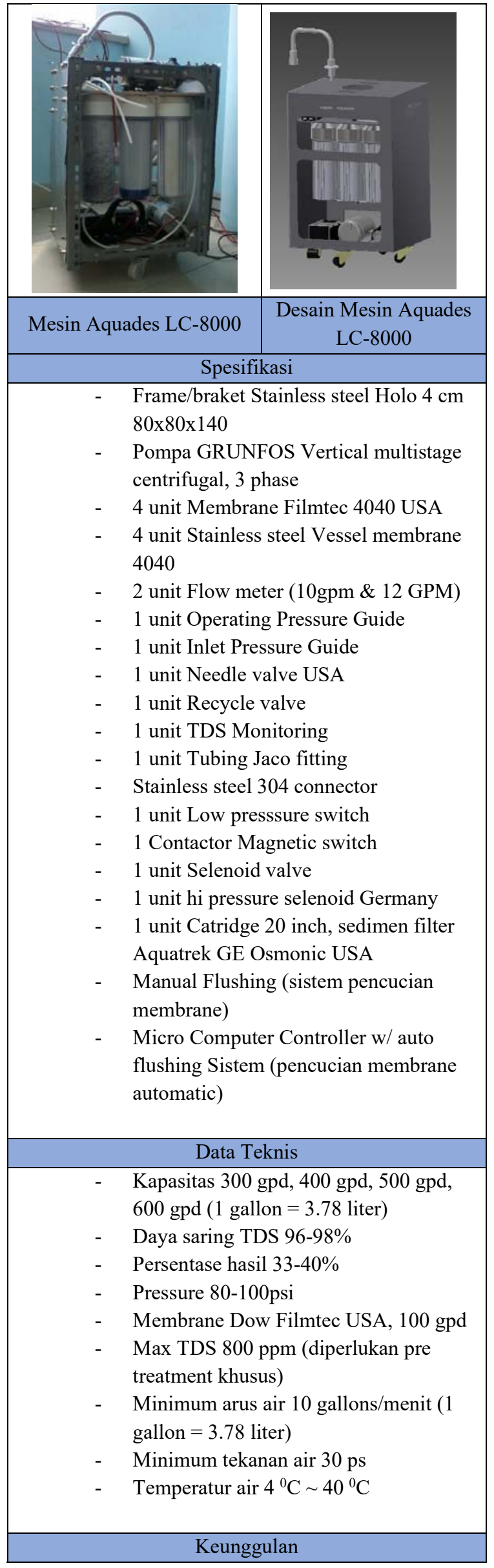

\begin{tabular}{|c|}
\hline $\begin{array}{ll}\text { - } & \text { Kebutuhan Energi relatif hemat. } \\
\text { - } & \text { Hemat Ruangan. } \\
\text { - } & \text { Mudah dalam pengoperasian karena } \\
\text { pengendalian operasi terpusat pada satu } \\
\text { panel yang kecil dan sederhana. } \\
\text { - } \quad \text { Kemudahan untuk menambah kapasitas. } \\
\text { - } \quad \text { Produksi airnya dapat langsung } \\
\text { diminum, tanpa dimasak dahulu. } \\
\text { - } \text { RO mudah dipindahkan ke lokasi lain } \\
\text { (ada yang terpasang dalam unit mobil } \\
\text { RO atau kontainer). }\end{array}$ \\
\hline Manfaat \\
\hline $\begin{array}{ll}\text { - } & \text { Mengurangi kadar keasaman darah } \\
\text { - } & \text { Menjaga dan meningkatkan kesegaran } \\
\text { tubuh } \\
\text { - } & \text { Mempercepat pengaruh daya larutan } \\
\text { - } & \text { Memperbaiki sirkulasi darah } \\
\text { - } & \text { Memperbaiki metabolisme } \\
\text { - } & \text { Mencegah pembiakan bakteri } \\
\text { - } & \begin{array}{l}\text { Membantu pertumbuhan dan } \\
\text { perkembangan }\end{array}\end{array}$ \\
\hline
\end{tabular}

a. Diagram Alir Sistem Aquades

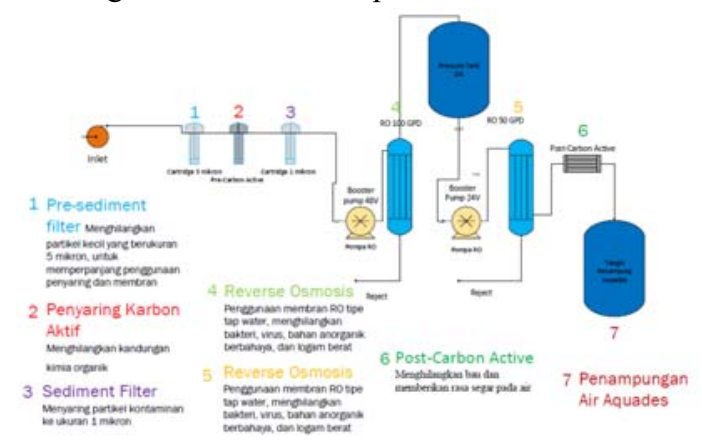

Gambar 3.4 Diagram Alir Sistem Aquades

Desain sistem aquades dibuat kubus untuk mengefisiensi tempat. Meskipun berbentuk kubus tidak mempengaruhi kinerja daripada aliran sistem aquades. Adapun plat yang digunakan berupa plat besi dan baut pengunci juga berbahan sejenis untuk menghindari korosi galvanis, yaitu korosi akibat perbedaan jenis bahan.

2. Re-desain dan Modifikasi Sistem Electrical Mixer Cement Kapasitas 208 Liter

Tabel 3.3 Spesifikasi Mesin Mixer Cement

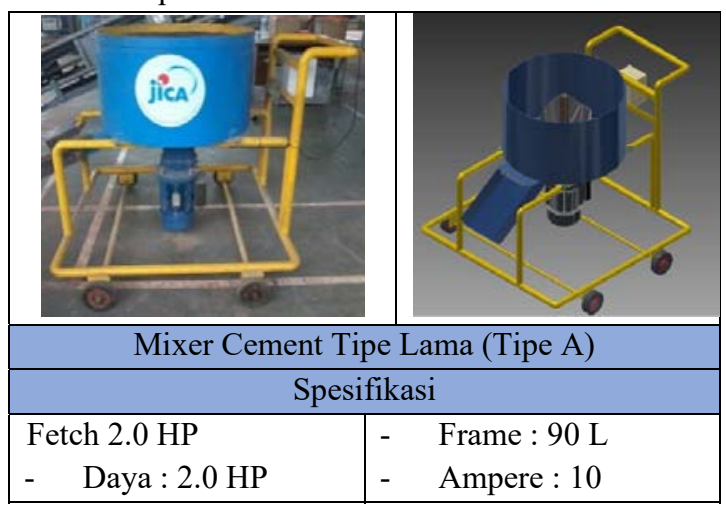




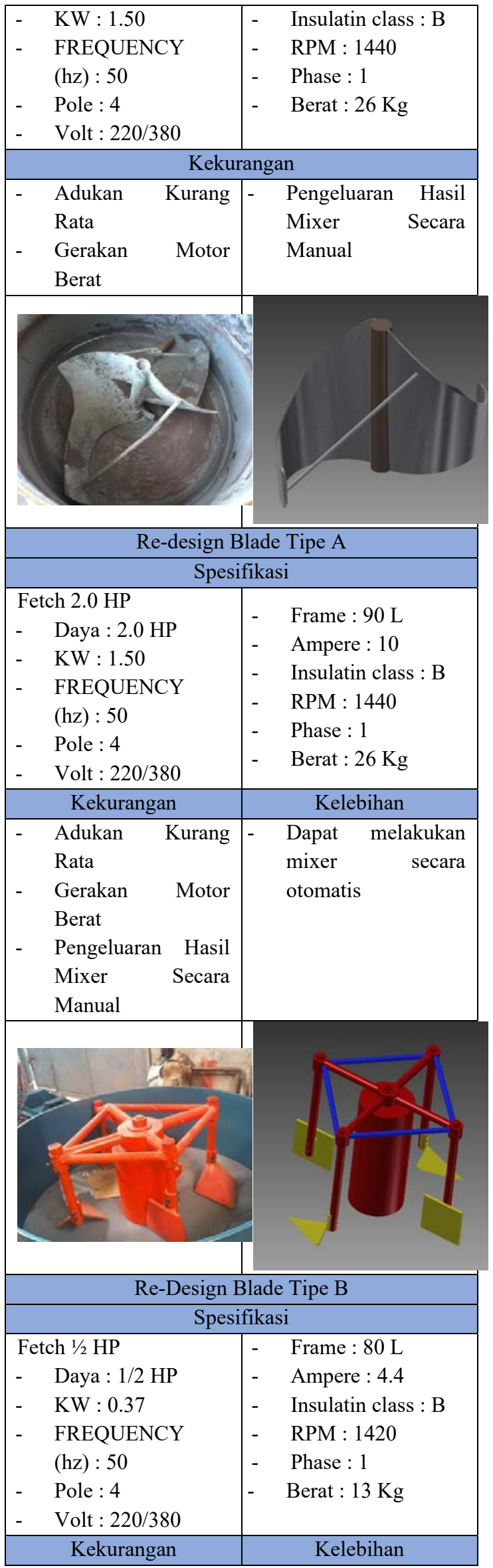

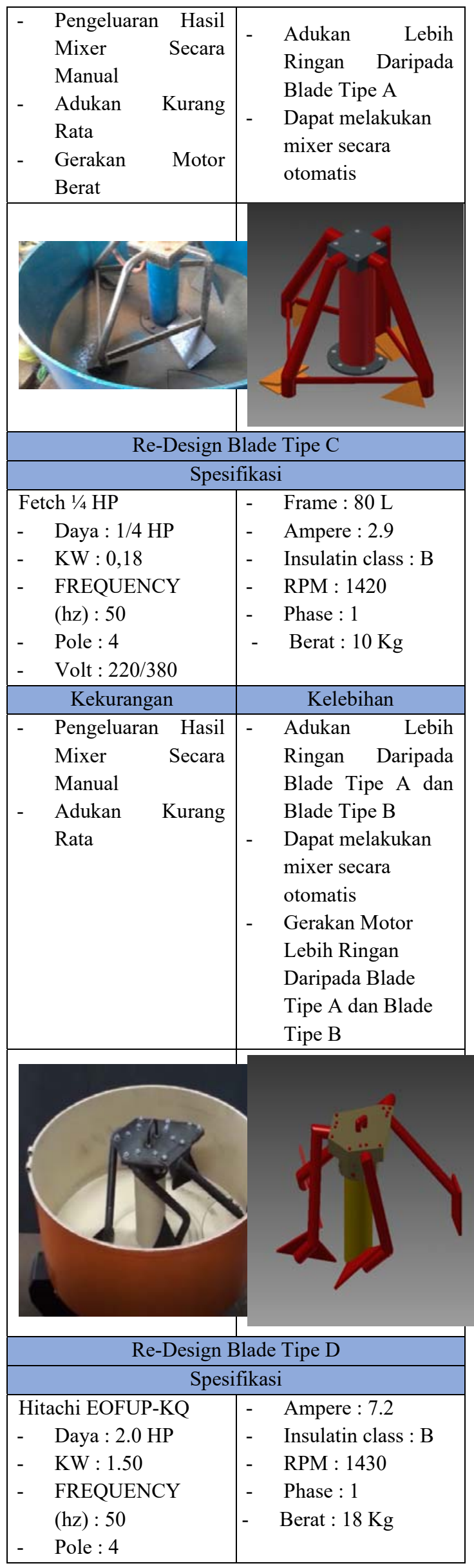




\begin{tabular}{|c|c|}
\hline - $\quad$ Volt : 220 & \\
\hline Kekurangan & Kelebihan \\
\hline & 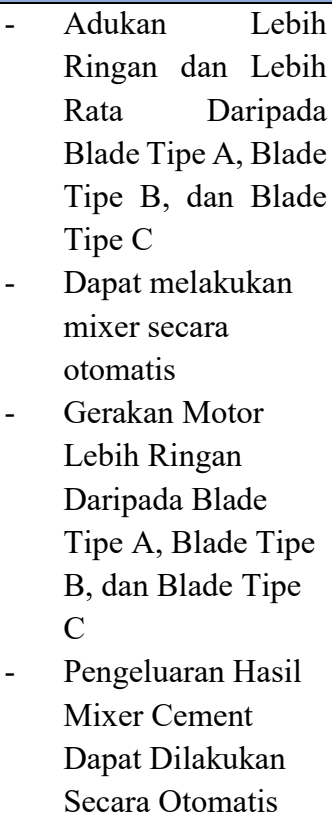 \\
\hline Design Rekomendasi Bla & le Tipe Terbaru (Tipe D) \\
\hline Spesit & ikasi \\
\hline $\begin{array}{ll}\text { Hitachi EOFUP-KQ } \\
\text { - } & \text { Daya }: 2.0 \mathrm{HP} \\
- & \text { KW }: 1.50 \\
- & \text { FREQUENCY }(\mathrm{hz}): \\
& 50 \\
- & \text { Pole }: 4 \\
- & \text { Volt }: 220\end{array}$ & $\begin{array}{ll}\text { - } & \text { Ampere : } 7.2 \\
\text { - } & \text { Insulatin class : B } \\
\text { - } & \text { RPM : } 1430 \\
\text { - } & \text { Phase }: 1 \\
\text { - } & \text { Berat }: 18 \mathrm{Kg}\end{array}$ \\
\hline Keleb & ihan \\
\hline 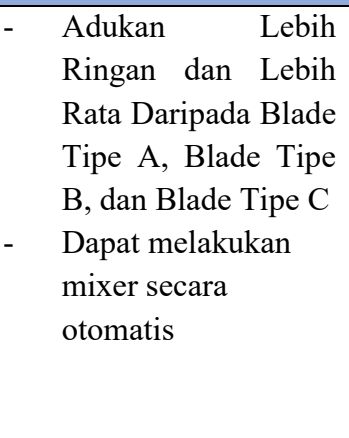 & 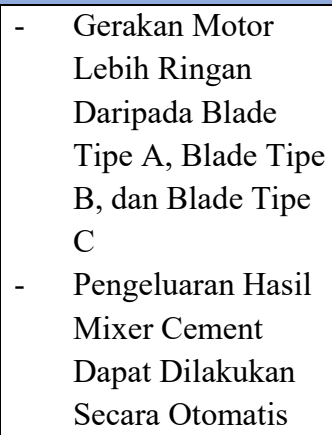 \\
\hline
\end{tabular}

a. Rangkaian Sistem Electrical untuk Gerak Blade 1 Arah

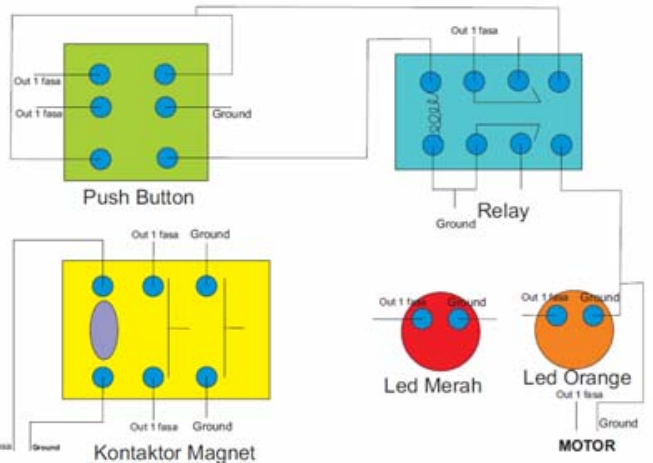

Gambar 3.5 Rangkaian Sistem Electrical untuk Gerak Blade 1 Arah

Sistem Electrical blade gerak 1 arah membuat hasil mixer kurang rata dan membutuhkan waktu cukup lama, sehingga rangkaian harus dimodifikasi menjadi gerak 2 arah.

a. Modifikasi Rangkaian Sistem Electrical untuk Gerak Blade 2 Arah

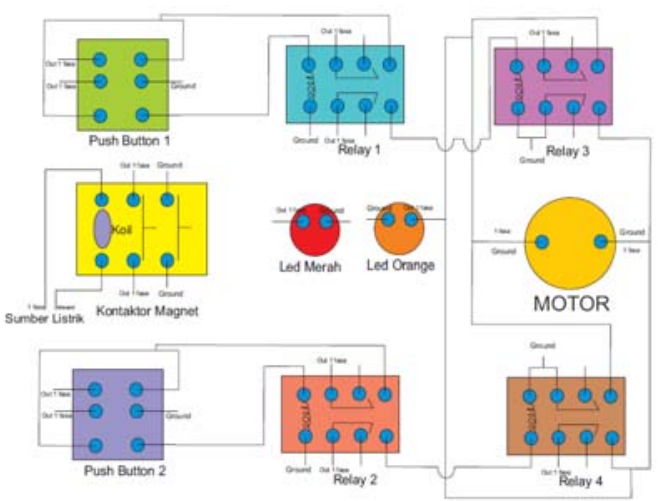

Gambar 3.6 Modifikasi Rangkaian Sistem Electrical untuk Gerak Blade 2 Arah

3. Pembongkaran Wind Turbin China untuk diganti dengan Wind Turbin A-Wina merk Jepang

Tabel 3.4 Spesifikasi Turbin China dan A-Wina

-
- Rated Power: $100 \mathrm{watt}$ efektif*
- $\quad$ Rated wind speed: $5 \mathrm{~m} / \mathrm{s}$
- $\quad$ Cut-in wind speed: $1.5 \mathrm{~m} / \mathrm{s}$
- $\quad$ Rotor diameter: $2 \mathrm{~m}$
Rated output voltage: $220 / 240 \mathrm{~V}$




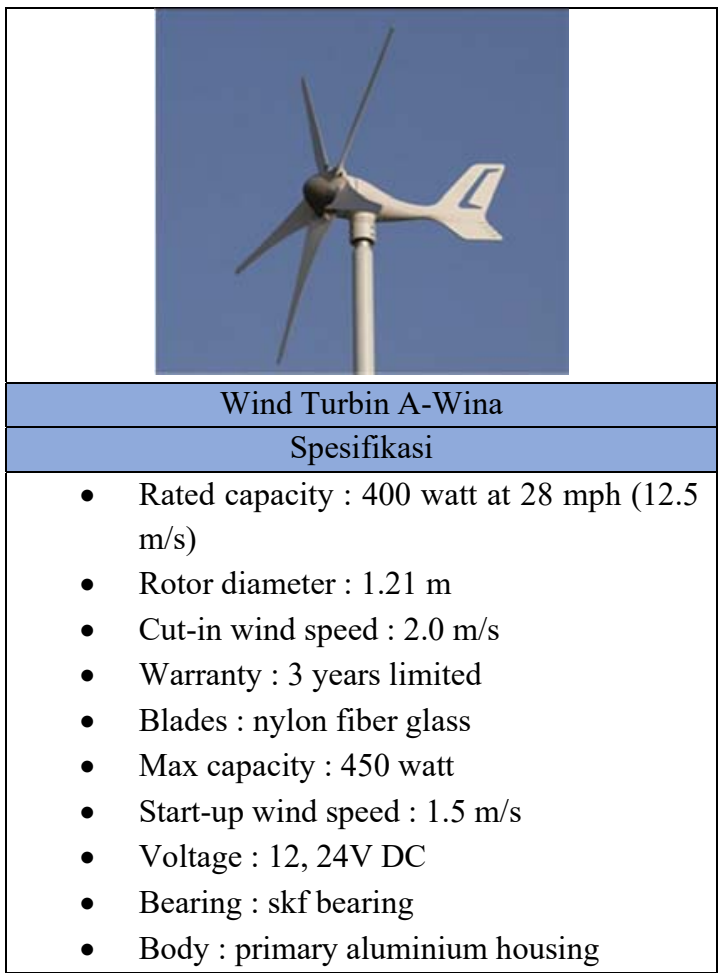

\section{SIMPULAN DAN SARAN}

Berdasarkan hasil penelitian diatas, dapat disimpulkan sebagai berikut :

1. Sistem aquades dengan bentuk kubus tidak memengaruhi aliran sistem, bahkan mengefisiensi tempat. Bahan yang digunakan adalah material sejenis yaitu besi untuk menghindari terjadinya korosi galvanis.

2. Mixer cement kapasitas $208 \mathrm{~L}$ yang paling bagus adalah Tipe D karena merupakan pengembangan dari mixer cement tipe $\mathrm{A}$, tipe $\mathrm{B}$, dan tipe $\mathrm{C}$ dengan keunggulan dapat menciptakan hasil mixing lebih rata serta pengeluaran hasil mixing secara otomatis. Adapun gerak mixer dibuat 2 arah akan lebih efektif dalam proses mixing dan efisien dalam tenaga karena sistem elektrikal dapat menciptakan gerakan self-konservatif. Indikator Blade Tipe D lebih baik dari blade tipe yang lain :

a) Adukan Lebih Ringan dan Lebih Rata Daripada Blade Tipe A, Blade Tipe B, dan Blade Tipe C

b) Dapat melakukan mixer secara otomatis

c) Gerakan Motor Lebih Ringan Daripada Blade Tipe A, Blade Tipe B, dan Blade Tipe C

d) Output hasil Mixer Cement Dapat Dilakukan Secara Otomatis

e) Turbin A-wina menggunakan teknologi berbasis nano, sehingga dengan kecepatan angin $3-6 \mathrm{~m} / \mathrm{s}$ sudah mampu memutarkan blade.

\section{REFERENSI}

[1] Anonim, Pengertian Relay dan Fungsinya. http://teknikelektronika.com/pengertian-relay-fungsirelay/di akses pada 12 Februari 2017

[2] Dermanto, Trikueni. Pengertian Push Button Switch. http://trikueni-desainsistem.blogspot.co.id/2014/04/Pengertian-PushButton.html\#more di akses pada 12 Februari 2017

[3] Irwan, Muhammad. Design Gambar Menggunakan Autodesk Inventor.

https://irwanmuhammad20.wordpress.com/pembelaja ran-design-gambar-menggunakan-program-autodeskinventor/ di akses pada 12 Februari 2017

[4] Nurmawan, Aji. Kontaktor Magnet. http://dunialistrikelektron.blogspot.co.id/2015/04/pen gertian-kontaktor-magnet-dan.html di akses pada 12 Februari 2017

[5] Rabith, Muhammad. Prinsip Kerja Motor Induksi 1 Fasa. $\quad$ http://dunialistrik.blogspot.co.id/2009/04/motor-listrik-ac-satufasa.html di akses pada 12 Februari 2017 